\title{
Pemecahan Masalah dalam Pembelajaran Melalui Kreativitas Guru Selama Masa Pandemi
}

\author{
Problem Solving In Learning Through Teacher Creativity During the Pandemic
}

\begin{abstract}
Author:
- Dwi Ariefin ${ }^{1}$

- I Putu Ayub

Darmawan ${ }^{2}$

Affiliation:

${ }^{1}$ Sekolah Tinggi Teologi

Baptis Indonesia

Semarang

dwiariefin@stbi.ac.id

2 Sekolah Tinggi Teologi

Simpson Ungaran

putuayub.simpson@gmail. com

Dates:

Submitted:

3 February 2021

Accepted:

3 April 2021

Published:

17 May 2021

DOI:

10.46494/psc.v17i1.122
\end{abstract}

\section{Copyright:}

(C) 2021. The Authors.

Licensee: Licensee:

PASCA. This work is

licensed under the

Creative Commons

Attribution-ShareAlike

4.0 International License.
Abstract: As a result of the Covid-19 pandemic, learning problems have arisen related to the use of technology for learning, to various impacts - and learning difficulties. For this purpose, an analysis of the results of studies on learning problems during the pandemic is carried out, as well as on the process of producing creativity. There were learning problems related to the existence of technology in learning, the readiness of learning persons, learning communication, and classroom management. Learning problems must be solved with creativity. Through creativity, the teacher will generate solution ideas that have the potential to effectively solve problems in learning.

[Akibat pandemi Covid-19, timbul masalah-masalah pembelajaran yang berkaitan dengan penggunaan teknologi untuk pembelajaran, hingga beragam dampak dan kesulitan pembelajaran. Untuk maksud tersebut, dilakukan analisis terhadap hasilhasil kajian tentang permasalahan pembelajaran saat pandemi, maupun tentang proses menghasilkan kreativitas. Ditemukan adanya masalah pembelajaran yang berkaitan dengan keberadaan teknologi dalam pembelajaran, kesiapan pelaku pembelajaran, komunikasi pembelajaran, serta tentang pengelolaan kelas. Masalahmasalah dalam pembelajaran harus dipecahkan dengan kreativitas. Melaluinya guru akan menghasilkan ide-ide solutif yang berpotensi efektif mengatasi masalah dalam pembelajaran.]

Research Contribution: This research provides confidence and encouragement to teachers and students to act creatively and innovatively in overcoming various learning problems during a pandemic through a problem-solving approach. The research provides ideas for developing a curriculum for teaching and learning strategies for education in the era of digitalization.

Keywords: education, learning, problem solving, creativity, pandemic.

\section{Pendahuluan}

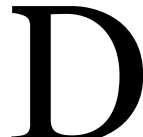

ampak kuat pandemi Covid-19 telah menimbulkan beragam masalah, termasuk bidang pendidikan di banyak negara. Pendidikan di Indonesia juga terdampak dengan pandemi yang bersifat global tersebut. Pemerintah meresponi dampak yang terjadi dengan membuat kebijakan dan himbauan untuk tidak melaksanakan pembelajaran secara konvensional atau dengan tatap muka, melainkan 
secara daring. ${ }^{1}$ Meskipun dengan menanggung segala konsekuensinya, para penyelenggara pendidikan pun menaati himbauan tersebut, agar pandemi terkendali.

Dalam pelaksanaannya, muncul masalahmasalah. Bermacam permasalahan dalam pembelajaran terjadi di lingkungan pendidikan formal, mulai dari PAUD, ${ }^{2}$ Sekolah Dasar,3 Sekolah Lanjutan, hingga Perguruan Tinggi.4 Aktifitas pendidikan non-formal juga terdampak, termasuk di lingkungan gereja.5 Pembelajaran di beragam lingkungan pendidikan menghadapi permasalahan pembelajaran pada saat pandemi ini. Masalahmasalah yang terjadi mulai dari yang berkaitan dengan keberadaan sarana, penguasaan teknologi, hingga pengelolaan dan proses berlangsungnya pembelajaran. ${ }^{6}$ Beberapa penelitian terdahulu menunjukkan, jika pandemi telah berdampak pada berbagai sektor dalam pendidikan.

Penelitian terbaru menemukan bahwa masalah-masalah harus diatasi dengan kreatif. Penelitian Hutapea menunjukkan adanya upaya guru untuk memecahkan masalah pembelajaran selama masa pandemi dengan kreativitas mengajar. Proses kreatif adalah bagian terikat dengan pemecahan masalah. 7 Nakin berpendapat, berpikir kreatif adalah

\footnotetext{
${ }^{1}$ Mendagri-RI Mendikbud, Menag, Menkes, Keputusan Bersama Tentang Panduan Penyelenggaraan Pembelajaran Pada Tahun Ajaran 2020/2021 Dan Tahun Akademik 2020/2021 Di Masa Pandemi Coronavirus Disease 2019 (Covid-19), MOR O3/KB/2O2O, NOMOR 612 TAHUN 2O2O, NOMOR HK.o1.o8/Menkes/5O2/2O2O, NOMOR 11, 2020.

2 Arifah Prima Satrianingrum and Iis Prasetyo,

"Persepsi Guru Dampak Pandemi Covid-19 Terhadap Pelaksanaan Pembelajaran Daring Di PAUD,” Jurnal Obsesi : Jurnal Pendidikan Anak Usia Dini 5, no. 1 (2020): 633 .

3 Mastura and Rustan Santaria, "Dampak Pandemi Covid-19 Terhadap Proses Pengajaran Bagi Guru Dan Siswa Pendahuluan," Jurnal Studi Guru dan

Pembelajaran 3, no. 2 (2020): 289-295.

4 Ali Sadikin and Afreni Hamidah, "Pembelajaran Daring Di Tengah Wabah Covid-19," Biodik 6, no. 2 (2020): 109-119.

5 Karnawati Karnawati and Mardiharto Mardiharto,

"Sekolah Minggu Masa Pandemi Covid 19: Kendala,
}

proses mensintesis berbagai konsep yang digunakan untuk memecahkan masalah. ${ }^{8}$ Pendapat Krutetski yang dikutip Park menguatkan bahwa kreativitas adalah kemampuan untuk menemukan solusi suatu masalah. 9 Kreativitas diperlukan untuk pemecahan masalah.

Pada bagian lain, penelitian tentang pemecahan masalah pembelajaran dengan kreatif masih terbatas, padahal masalah-masalah pembelajaran dalam masa pandemi ini perlu segera diatasi.

Pemecahan masalah-masalah dalam pembelajaran sangat memerlukan kreativitas. Penelitian tentang hal tersebut sangat diperlukan. Pemecahan masalah dalam pembelajaran memang menjadi tanggung jawab berbagai pihak yang terkait. Meski demikian, guru sebagai pembelajar tentu terpanggil untuk melancarkan pembelajaran dan pendidikan. ${ }^{10}$ Terutama dalam aspek praktisnya, pemecahan masalah dan kelancaran pembelajaran adalah bagian dari tanggung jawab seorang guru. Guru perlu memahami persoalan, mengerti kepentingan kreativitas, mencoba menghasilkan kreativitas, serta mendapatkan contoh ide-ide solusi. Dengan demikian guru terdorong untuk memecahkan masalah dengan kreativitas.

Solusi, Proyeksi," Didache: Journal of Christian Education 1, no. 1 (2020): 13.

6 Ari Budi Santosa, "Potret Pendidikan Di Tahun Pandemi : Dampak COVID-19 Terhadap Disparitas Pendidikan Di Indonesia," CSIS Commentaries (2020): $1-5$.

7 Rinto Hasiholan Hutapea, "Kreativitas Mengajar Guru Pendidikan Agama Kristen Di Masa Covid-19," Didache: Journal of Christian Education 1, no. 1 (June 2020): 1. 8 J. B. Nakin, "Creativity and Divergent Thinking In Geometry Education," Creativity and Divergent Thinking, no. November (2014).

9 Hija Park, "The Effects of Divergent Production Activities with Math Inquiry and Think Aloud of Students with Math Difficulty. Doctoral Dissertation," (Texas A\&M University, 2004).

10 Mardiharto Mardiharto, "Pembangunan Sumber Daya Manusia Melalui Bidang Pendidikan Agama Kristen,” PASCA : Jurnal Teologi dan Pendidikan Agama Kristen 15 (2019): 28-32. 
Situasi dan problematika di atas memunculkan pertanyaan, bagaimana masalah dalam pembelajaran dapat dipecahkan melalui guru dengan kreativitasnya. Penelitian ini akan menelaah konsep dan prinsip penyelesaian masalah pembelajaran dengan kreativitas guru serta mengajukan ide-ide praktisnya.

\section{Metode}

Untuk mendapatkan temuan-temuan dari hasil karya ilmiah, maka dilakukan eksplorasi terhadap artikel-artikel jurnal dan sumbersumber ilmiah. Terhadap sumber-sumber tersebut dilakukan Literature Review. ${ }^{11}$ Dalam kegiatan ini dilakukan identifikasi dan pemilahan terhadap sumber-sumber yang relevan dengan topik penelitian ini; kemudian dilakukan evaluasi dan pembuatan rangkuman.12 Dari kegiatan tersebut terkumpul data kualitatif yang digunakan untuk menjawab pertanyaan penelitian ini. Literature Review terhadap hasil-hasil kajian tentang masalah-masalah pembelajaran saat pandemi Covid-19 ditemukan dan didaftarkan. Demikian pula dilakukan terhadap kajian tentang langkah atau proses menghasilkan kreativitas. Kedua kelompok data tersebut digunakan untuk kegiatan penerapan. Langkah-langkah dalam proses kreativitas diterapkan oleh peneliti untuk menghasilkan beberapa ide-ide solusi bagi masalah-masalah pembelajaran yang sudah didaftarkan. Hubungan masalah-masalah pembelajaran

\footnotetext{
${ }^{11}$ Sonny Eli Zaluchu, "Metode Penelitian Di Dalam Manuskrip Jurnal Ilmiah Keagamaan,” Jurnal Teologi Berita Hidup 3, no. 2 (March 25, 2021): 249-266, https://e-

journal.sttberitahidup.ac.id/index.php/jbh/article/view /93.

${ }^{12}$ Agustin Soewitomo Putri, “Tips Dan Trik Pemilihan Dan Penyusunan Literatur Review," in Strategi Menulis Jurnal Untuk Ilmu Teologi, ed. Sonny Eli Zaluchu (Semarang: Golden Gate Publishing, 2020), 49-50; Kevin Gary Smith, Writing and Research: A Guide for Theological Students (Cumbria: Langham Global Library, 2016).
}

dengan ide-ide solusi ditampilkan dalam tabeltabel. Daftar dalam tabel tersebut juga dikolaborasi bersama konsep pentingnya mengatasi masalah dengan kreativitas. Akhirnya, ditemukan konsep yang disertai contoh-contoh ide solusi, terkait pengembangan kreativitas oleh guru untuk mengatasi masalah dalam pembelajaran saat pandemi.

\section{Pembahasan}

\section{Kategori dan Macam Masalah Pembelajaran}

Dari berbagai penelitian telah ditemukan bahwa masalah pembelajaran yang timbul berkaitan dengan ketersediaan alat dan biaya, ketidakcukupan pengalaman menjalankan pembelajaran daring, ${ }^{13}$ keterbatasan kemampuan guru; ${ }^{14}$ serta sejumlah kesulitan pada peserta pembelajaran, yaitu murid atau mahasiswa, seperti menjadikan mereka pasif, kurang kreatif atau mengalami penumpukan informasi. ${ }^{15}$

Masalah-masalah tersebut terkelompokkan sebagai masalah penguasaan teknologi, ketersediaan sarana, proses pembelajaran, metode, kesiapan guru, serta kesiapan murid. ${ }^{16}$ Kesemuanya dapat dikategorikan secara ringkas sebagai masalah pembelajaran terkait keberadaan teknologi dalam pembelajaran, kesiapan pelaku pembelajaran, komunikasi pembelajaran, serta pengelolaan kelas.

\footnotetext{
${ }^{13}$ Ahmad Muzawir Saleh, "Problematika Kebijakan Pendidikan Di Tengah Pandemi Dan Dampaknya Terhadap Proses Pembelajaran Di Indonesia," Jurnal Pendidikan 2, no. 2 (2020): 24-24.

${ }^{14}$ Asmuni Asmuni, "Problematika Pembelajaran Daring Di Masa Pandemi Covid-19 Dan Solusi Pemecahannya," Jurnal Paedagogy 7, no. 4 (2020): 281.

${ }_{15}$ Niken Bayu Argaheni, "Sistematik Review: Dampak Perkuliahan Daring Saat Pandemi COVID-19 Terhadap Mahasiswa Indonesia," PLACENTUM: Jurnal Ilmiah Kesehatan dan Aplikasinya 8, no. 2 (2020): 99.

${ }^{16}$ Santosa, "Potret Pendidikan Di Tahun Pandemi : Dampak COVID-19 Terhadap Disparitas Pendidikan Di
} Indonesia." 


\section{Pemecahan Masalah dengan Kreativitas}

Ide-ide kreatif memang dapat muncul secara tiba-tiba, namun sebenarnya melalui sebuah proses juga. ${ }^{17}$ Hasil telaah Munandar menginformasikan bahwa kreativitas diperoleh dengan berpikir menyebar, serta memiliki karakteristik fleksibilitas, keaslian, elaborasi, faktor kebermanfaatan dan efektivitas. ${ }^{18}$ Berpikir menyebar (divergen) adalah pola berpikiran ke berbagai arah untuk menemukan bermacam kemungkinan, menggunakan pendekatan langsung dan kreatif dengan penalaran yang tidak segera dapat dijelaskan (lateral ) bahkan tidak rasional; menyangkut pemikiran sekitar atau yang menyimpang dari pusat persoalan. Dengan berpikir menyebar akan dapat menyatukan berbagai ide terpisah ke dalam satuan ide baru yang utuh. ${ }^{19}$ Melalui berpikir demikian, dihasilkan kreativitas, yaitu proses mencari hubungan-hubungan baru, atau kombinasi-kombinasi baru dari antarunsur, data dan hal-hal yang sudah ada sebelumnya untuk menjawab suatu persoalan menjadi suatu bentuk yang nyata.

Proses menghasilkan kreativitas melalui beberapa tahap atau langkah. Menurut Scarborough dan Zimmerer yang dikutip Kabukcu, ${ }^{20}$ terdapat tujuh langkah dalam proses tersebut, yaitu: Persiapan, Investigasi, Transformasi, Inkubasi, Iluminasi, Verifikasi dan Implementasi. Bagi pemecahan masalah dalam pembelajaran, langkah-langkah dalam proses kreatif tersebut perlu dilalui. Pertama, mengingat kembali pengetahuan yang sudah dimiliki terkait permasalahan. Kedua, melakukan investigasi dan mengumpulkan informasi untuk memahami permasalahan dan situasinya. Ketiga, melakukan transformasi,

\footnotetext{
17 Jati Fatmawati, Telaah Kreativitas (Surabaya, 2018).

18 Utami Munandar, Pengembangan Kreativitas Anak

Berbakat. (Jakarta: Rineka Cipta, 2009).

19 I.Munawaroh \& Hariyanto, "Neuroscience Dalam

Pembelajaran," Majalah Ilmiah Pembelajaran

(Yogyakarta: Majalah Ilmiah Pembelajaran, 2005).

${ }^{20}$ Evrim Kabukcu, "Creativity Process in Innovation

Oriented Entrepreneurship: The Case of Vakko,"
}

yaitu melihat perbedaan dan persamaan dari informasi-informasi. Persamaan dan hubungan antara data dan fakta dilihat secara memusat (konvergen). Perbedaan-perbedaan data dan fakta dilihat secara menyebar (divergen). Pada langkah divergen ini, permasalahan dipandang dari beberapa sisi, menyebar ke berbagai arah untuk menemukan banyak jawaban, bersifat menyeluruh dan tidak teramalkan. ${ }^{21}$ Keempat, memunculkan ide-ide yang berpotensi menyelesaikan masalah. Kelima, melakukan inkubasi yakni menyimpan ide yang muncul untuk sementara. Keenam, melakukan verifikasi ide-ide, yaitu dalam hal kepraktisan, tingkat keberhasilan serta konsekuensinya. Ketujuh, menerapkan ide terpilih untuk mengatasi permasalahan. Dengan langkahlangkah tersebut, maka pemecahan masalah dalam pembelajaran dapat dilakukan secara kreatif.

Proses penting dalam kreativitas adalah berpikir menyebar dan keberanian berpikiran tidak biasa. Kreativitas yang baik akan menghasilkan sesuatu yang unik, baru, atau kombinasi-kombinasi dari yang lama. Pemecahan masalah secara kreatif adalah menemukan masalah, menghasilkan kebaruan, mendefinisikan solusi, dan mengenali solusi, ${ }^{22}$ bagi aktifitas pembelajaran.

\section{Pemecahan Masalah Keberadaan Teknologi dalam Pembelajaran}

Kajian tentang masalah pembelajaran terkait keberadaan teknologi dalam pembelajaran dapat dikategorikan sebagai masalah ketersediaan sarana dan masalah pembiayaan. ${ }^{23}$ Peneliti menerapkan langkahlangkah kreativitas untuk menghasilkan contoh-contoh ide solusi. Tabel 1 adalah tabel

Procedia - Social and Behavioral Sciences 195, no. July 2015 (2015): 1321-1329.

${ }^{21}$ I.Munawaroh \& Hariyanto, "Neuroscience Dalam

Pembelajaran."

${ }^{22}$ Cropley A.J, "Problem-Solving and Creativity:

Implications for Classroom Assessment.," Leicester, UK:

British Psychological Society. (2005).

${ }^{23}$ Sadikin and Hamidah, "Pembelajaran Daring Di Tengah Wabah Covid-19." 
Tabel 1: Masalah Keberadaan Teknologi dan Contoh Ide Solusinya

\begin{tabular}{lll}
\hline Kategori & Ide Solusi \\
\hline Ketersedia & 1. Optimalisasi sarana (teknologi informasi) yang dimiliki \\
\hline Pembiayaa & 2. Menggunakan sarana yang ada di lembaga \\
$\boldsymbol{n}$ & 2. Efisiensi penggunaan kuota melalui pengaturan aplikasi komunikasi \\
& 3. Pengajuan resmi untuk dukungan dari otoritas Lembaga \\
& Penyelenggara Pendidikan \\
\hline
\end{tabular}

perkembangan teknologi,25 dan semestinya menguasainya untuk kepentingan belajar dan pembelajaran. ${ }^{26}$ Masa pandemi dan kenormalan baru memaksa pelaku pembelajaran untuk menghadapi kebiasaan baru dengan penggunaan teknologi dalam pembelajaran. ${ }^{27}$

Pada kenyataannya, telah ditemukan bahwa pelaku pembelajaran, baik pembelajar (guru atau dosen), dan peserta (murid atau mahasiswa) mengalami masalah ketidaksiapan dalam menghadapi penggunaan teknologi informasi dan komunikasi dalam pembelajaran. ${ }^{28}$ Para pelaku pembelajaran tidak siap untuk mampu dan terampil menggunakan teknologi dalam pembelajaran.

Dengan mengetahui masalah-masalah yang terkait, serta dengan menerapkan langkahlangkah kreatif, peneliti mengajukan contohcontoh ide solusi. Contoh-contohnya disusun di dalam Tabel 2.

\section{Pemecahan Masalah Kesiapan Pelaku Pembelajaran}

Dari segi lain, masalahmasalah terkait teknologi dalam pembelajaran sebenarnya merupakan tantangan juga bagi guru dan murid. Pada era revolusi indutri 4.0 ini, para pelaku pendidikan tidak dapat lepas dari pengaruh perkembangan teknologi. ${ }^{24}$ Era globalisasi menuntut pelaku pembelajaran menyesuaikan dengan

\footnotetext{
24 Mariani Harmadi and Agung Jatmiko, "Pembelajaran Efektif Pendidikan Agama Kristen Generasi Milenial," PASCA : Jurnal Teologi dan Pendidikan Agama Kristen 16, no. 1 (2020): 62-74.

25 B. Husnani, Zaibi, Rollies, "Tantangan Guru Di Era Kekinian," Prosiding Seminar Nasional Pendidikan Program Pascasarjana Universitas PGRI Palembang (2019): 348-356.
}

Masalah ketidaksiapan dapat diupayakan solusinya. Baik solusi yang bersifat sederhana maupun yang memberi tantangan. Sangat

\footnotetext{
26 Dwi Ariefin, Media Pembelajaran Teknologis

(Semarang: Lentera Hikmat, 2018).

${ }_{27}$ Hutapea, "Kreativitas Mengajar Guru Pendidikan Agama Kristen Di Masa Covid-19."

${ }^{28}$ Asmuni, "Problematika Pembelajaran Daring Di Masa Pandemi Covid-19 Dan Solusi Pemecahannya."
} 
mungkin ada konsekuensi, kesulitan dan tantangan lanjutan akibat penerapan ide-ide tersebut. Namun demikian, ide-ide unik, berani dan tidak biasa harus dihasilkan dan diperjuangkan pelaksanaannya.

\section{Pemecahan Masalah dalam Berkomunikasi}

Persoalan menonjol yang terjadi dengan pembelajaran secara daring adalah terbatas atau tidak lancarnya proses komunikasi. Guru dan murid hanya dapat berkomunikasi tidak langsung berbentuk suara, gambar dan video melalui media berteknologi, seperti telepon genggam, Laptop dan Komputer. ${ }^{29}$ Komunikasi dan interaksi yang terjadi tidak dapat secara langsung atau tatap muka. Komunikasi dan interaksi pembelajaran dilangsungkan secara virtual. Cara ini menimbulkan beberapa kesulitan, seperti keterbatasan waktu, kebosanan dan kesulitan mengawasi.30 Permasalahan berkaitan komunikasi pembelajaran dikategorikan dalam masalah kesempatan berkomunikasi dan masalah interaksi pembelajaran.

Menghadapi permasalahan tersebut, guru dituntut lebih kreatif dalam berkomunikasi. Dengan menerapkan langkah-langkah kreatif sebagaimana diterangkan di bagian atas, dapat dihasilkan ide-ide solusinya. Berikut ini disajikan sejumlah ide solusi, seperti ditunjukkan pada Tabel 3 .

Gagasan unik dapat dimunculkan untuk mengatasi masalah berkomunikasi. Variasi-

\footnotetext{
${ }^{29}$ Henry Aditia Rigianti, "Kendala Pembelajaran Daring Guru Sekolah Dasar Di Banjarnegara," Elementary School: Jurnal Pendidikan dan Pembelajaran ke-SDan 7, no. 2 (July 2020): 297-302.

30 Andri Anugrahana, "Hambatan, Solusi Dan Harapan: Pembelajaran Daring Selama Masa Pandemi Covid-19 Oleh Guru Sekolah Dasar,” Scholaria: Jurnal
}

variasi berkomunikasi dan berinteraksi perlu dimunculkan; seperti dengan mengatur waktu kesempatan interaksi, variasi tempat, aplikasi yang digunakan bahkan dalam pilihan jenis komunikasinya, verbal atau non-verbal. Ide-ide solusi bagi masalah komunikasi pembelajaran yang berkualitas perlu konsisten diimplementasikan untuk penyelesaian masalah pembelajaran.

Tabel 3: Masalah Berkomunikasi dan Contoh Ide Solusinya

\begin{tabular}{lll}
\hline Kategori & Ide Solusi \\
\hline $\begin{array}{l}\text { Kesempatan } \\
\text { serkomunika }\end{array}$ & 1. & $\begin{array}{l}\text { Menambah variasi waktu, sebagian waktu pada pagi, sebagian } \\
\text { lain pada sore hari. }\end{array}$ \\
& 2. & $\begin{array}{l}\text { Memanfaatkan Aplikasi populer di kalangan murid untuk } \\
\text { pembelajaran, misalnya dengan aplikasi WhatsApp, Youtube, } \\
\text { Facebook, Instagram, TikTok, dan lain sebagainya }\end{array}$ \\
\hline $\begin{array}{l}\text { Interaksi } \\
\text { Pembelajaran }\end{array}$ & 1. & $\begin{array}{l}\text { Guru berada di kelas, murid-murid diajar secara daring. Suasana } \\
\text { tetap seperti dikelas, meskipun kenyataannya secara daring. }\end{array}$ \\
& 2. & $\begin{array}{l}\text { Mengkombinasikan aplikasi pembelajaran. } \\
\text { 3enurunkan kelemahan komunikasi virtual. }\end{array}$ \\
& 4. & $\begin{array}{l}\text { Metode ceramah dengan demonstrasi atau peragaan akan lebih } \\
\text { menarik dan mendukung pencapaian tujuan. }\end{array}$ \\
& 5. & $\begin{array}{l}\text { Memvariasi dalam mimik dan ekspresi wajah. Guru tidak hanya } \\
\text { bicara dengan ekspresi datar, namun bervariasi sesuai topik dan } \\
\text { situasi. }\end{array}$ \\
\end{tabular}

\section{Pemecahan Masalah dalam Pengelolaan Kelas}

Masalah pembelajaran lainnya yang terjadi pada masa pandemi adalah berkaitan pengelolaan kelas. Dalam masalah ini, pelaku pembelajaran juga mengalami berbagai kesulitan, hambatan dan dampak buruk. ${ }^{31}$ Dengan kelas secara daring, proses pembelajaran sering kali menjadi tidak lancar atau tersendat. ${ }^{2}$ Guru mengalami kesulitan untuk melakukan pengendalian proses pembelajaran. Dengan kelas daring, murid bersikap pasif dan kurang kreatif; demikian pula mengalami penumpukan informasi yang membuat mereka tertekan.

Pendidikan dan Kebudayaan 10, no. 3 (September 2020): 282-289.

${ }^{31}$ Argaheni, "Sistematik Review: Dampak Perkuliahan Daring Saat Pandemi COVID-19 Terhadap Mahasiswa Indonesia."

32 Anugrahana, "Hambatan, Solusi Dan Harapan: Pembelajaran Daring Selama Masa Pandemi Covid-19 Oleh Guru Sekolah Dasar." 
Dengan memerhatikan situasi dan kondisi masing-masing, guru dapat menggagas kreativitas dalam hal metode pembelajaran, mengatur personalia pembelajar serta menurunkan kesulitan yang dialami murid. Pada Tabel 4 digambarkan kategori permasalahan dan contoh solusinya.

Tabel 4: Masalah Pengelolaan Kelas dan Contoh Ide Solusinya

\begin{tabular}{lll}
\hline Kategori & Ide Solusi \\
\hline Metode & 1. & Kombinasi antara daring dan tatap muka. \\
$\boldsymbol{n}$ & 2. & Kombinasi antara daring dan tertulis. \\
& 3. & $\begin{array}{l}\text { Penggunaan metode penemuan atau inkuiri untuk meningkatkan } \\
\text { keaktifan peserta (murid). }\end{array}$ \\
\hline Pembelajar & 1. & Guru bekerjasama dengan orang tua \\
& 2. & Guru bekerjasama dengan pihak lain yang berada dekat murid \\
\hline Masalah & 1. & Guru berada di kelas, murid-murid diajar secara daring. Suasana \\
Pada Murid & & tetap seperti dikelas, meskipun kenyataannya secara daring. \\
& 2. & Mengkombinasikan aplikasi pembelajaran. \\
& 3. & Menurunkan kelemahan komunikasi virtual. \\
& 4. & Metode ceramah dengan demonstrasi atau peragaan akan lebih \\
menarik dan mendukung pencapaian tujuan. & \\
& 5. & $\begin{array}{l}\text { Memvariasi dalam mimik dan ekspresi wajah. Guru tidak hanya } \\
\text { bicara dengan ekspresi datar, namun bervariasi sesuai topik dan } \\
\text { situasi. }\end{array}$ \\
&
\end{tabular}

\section{Kesimpulan}

Akibat pandemi timbul masalah-masalah pembelajaran yang dapat dikelompokkan dalam masalah berkaitan keberadaan teknologi dalam pembelajaran, kesiapan pelaku pembelajaran, komunikasi pembelajaran dan pengelolaan kelas. Bagi pemecahan masalahmasalah tersebut, sangat diperlukan kreativitas. Langkahlangkah proses kreativitas perlu ditempuh untuk menghasilkan ideide kreatif dan solutif yang berpotensi untuk mengatasi masalah pembelajaran saat pandemi. Pemecahan masalah pembelajaran ditempuh melalui tahap mendaftarkan masalahmasalah, menjalankan langkahlangkah kreativitas, serta menghasilkan ide-ide kreatif dan solutif. Pemecahan masalah pembelajaran saat

Guru kreatif dapat mencoba untuk menerapkan ide solusi berkaitan dengan metode, pelaksana pembelajaran, serta masalah-masalah pada murid seperti dicontohkan di atas. Penerapan ide-ide tersebut menjadi hal penting untuk memecahkan masalah pengelolaan kelas pada saat pandemi.

Masalah-masalah pembelajaran saat pandemi, dapat dikelompokkan menurut keterkaitannya, yaitu berkaitan keberadaan teknologi dalam pembelajaran, kesiapan pelaku pembelajaran, komunikasi pembelajaran, serta berkaitan pengelolaan kelas. Pemecahan masalahmasalah tersebut memerlukan kemampuan berpikir kreatif. Kreativitas melalui sebuah proses. Pengembangan secara sadar dapat dilakukan dengan langkah-langkah kreativitas, mulai dari mengingat informasi yang terkait hingga penerapan ide-ide yang dihasilkan. Dengan proses kreativitas tersebut, dihasilkan berbagai kemungkinan solusi bagi masalah dalam pembelajaran. pandemi dengan kreativitas berarti memahami permasalahan serta mengimplementasikan langkah-langkah kreatif untuk menghasilkan ide-ide solusi masalah pembelajaran.

\section{Kontribusi Penelitian:}

Penelitian ini memberikan keyakinan dan dorongan kepada guru dan murid untuk bertindak kreativitas dan inovatif dalam mengatasi berbagai masalah pembelajaran saat pandemi melalui pendekatan pemecahan masalah. Penelitian memberi ide bagi pengembangan kurikulum strategi belajar mengajar pendidikan di era digitalisasi.

\section{Rekomendasi Penelitian Lanjutan:}

Perlu dilakukan penelitian dengan metode lain yang lebih mendalam. Survei dengan wawancara kepada guru dan murid akan lebih baik. Perlu juga penelitian yang berfokus kepada ragam masalah yang dihadapi guru dan murid, maupun tentang ide-ide solusi kreatif yang sudah dihasilkan para guru. Demikian pula dapat dilanjutkan dengan penelitian lebih mendalam menurut kelompok-kelompok permasalahan pembelajaran yang terjadi. 


\section{Referensi}

A.J, Cropley. "Problem-Solving and Creativity: Implications for Classroom Assessment." Leicester, UK: British Psychological Society. (2005).

Abidah, Azmil, Hasan Nuurul Hidaayatullaah, Roy Martin Simamora, Daliana Fehabutar, and Lely Mutakinati. "The Impact of Covid-19 to Indonesian Education and Its Relation to the Philosophy of 'Merdeka Belajar." Studies in Philosophy of Science and Education 1, no. 1 (2020): 38-49.

Anugrahana, Andri. "Hambatan, Solusi Dan Harapan: Pembelajaran Daring Selama Masa Pandemi Covid-19 Oleh Guru Sekolah Dasar." Scholaria: Jurnal Pendidikan dan Kebudayaan 10, no. 3 (September 2020): 282-289.

Argaheni, Niken Bayu. "Sistematik Review: Dampak Perkuliahan Daring Saat Pandemi COVID-19 Terhadap Mahasiswa Indonesia." PLACENTUM: Jurnal Ilmiah Kesehatan dan Aplikasinya 8, no. 2 (2020): 99.

Ariefin, Dwi. Media Pembelajaran Teknologis. Semarang: Lentera Hikmat, 2018.

Asmuni, Asmuni. "Problematika Pembelajaran Daring Di Masa Pandemi Covid-19 Dan Solusi Pemecahannya." Jurnal Paedagogy 7, no. 4 (2020): 281.

Fatmawati, Jati. Telaah Kreativitas. Surabaya, 2018.

Harmadi, Mariani, and Agung Jatmiko.

"Pembelajaran Efektif Pendidikan Agama Kristen Generasi Milenial." PASCA : Jurnal Teologi dan Pendidikan Agama Kristen 16, no. 1 (2020): 6274.

Husnani, Zaibi, Rollies, B. "Tantangan Guru Di Era Kekinian.” Prosiding Seminar Nasional Pendidikan Program Pascasarjana Universitas PGRI Palembang (2019): 348-356.

Hutapea, Rinto Hasiholan. "Kreativitas Mengajar Guru Pendidikan Agama Kristen Di Masa Covid19." Didache: Journal of Christian Education 1, no. 1 (June 2020): 1.

I.Munawaroh \& Hariyanto. "Neuroscience Dalam Pembelajaran.” Majalah Ilmiah Pembelajaran. Yogyakarta: Majalah Ilmiah Pembelajaran, 2005.

Kabukcu, Evrim. "Creativity Process in Innovation Oriented Entrepreneurship: The Case of Vakko." Procedia - Social and Behavioral Sciences 195, no. July 2015 (2015): 1321-1329.

Karnawati, Karnawati, and Mardiharto Mardiharto. "Sekolah Minggu Masa Pandemi
Covid 19: Kendala, Solusi, Proyeksi.” Didache: Journal of Christian Education 1, no. 1 (2020): 13.

Mardiharto, Mardiharto. "Pembangunan Sumber Daya Manusia Melalui Bidang Pendidikan Agama Kristen." PASCA : Jurnal Teologi dan Pendidikan Agama Kristen 15 (2019): 28-32.

Mastura, and Rustan Santaria. "Dampak Pandemi Covid-19 Terhadap Proses Pengajaran Bagi Guru Dan Siswa Pendahuluan." Jurnal Studi Guru dan Pembelajaran 3, no. 2 (2020): 289-295.

Mendikbud, Menag, Menkes, Mendagri-RI. Keputusan Bersama Tentang Panduan Penyelenggaraan Pembelajaran Pada Tahun Ajaran 2020/2021 Dan Tahun Akademik 2020/2021 Di Masa Pandemi Coronavirus Disease 2019 (Covid-19), MOR o3/KB/2O2O, NOMOR 612 TAHUN 2O2O, NOMOR HK.o1.o8/Menkes/5O2/2O2O, NOMOR 11, 2020.

Munandar, Utami. Pengembangan Kreativitas Anak Berbakat. Jakarta: Rineka Cipta, 2009.

Nakin, J. B. "Creativity and Divergent Thinking In Geometry Education." Creativity and Divergent Thinking, no. November (2014).

Onyema, Edeh Michael, Nwafor Chika Eucheria, Faith Ayobamidele Shuvro Sen, Fyneface Grace Atonye, Aabha Sharma, and Alhuseen Omar Alsayed. "Impact of Coronavirus Pandemic on Education." Journal of Education and Practice 11, no. 13 (2020): 108-121.

Park, Hija. "The Effects of Divergent Production Activities with Math Inquiry and Think Aloud of Students with Math Difficulty. Doctoral Dissertation,.” Texas A\&M University, 2004.

Putri, Agustin Soewitomo. "Tips Dan Trik Pemilihan Dan Penyusunan Literatur Review.” In Strategi Menulis Jurnal Untuk Ilmu Teologi, edited by Sonny Eli Zaluchu, 49-50. Semarang: Golden Gate Publishing, 2020.

Rigianti, Henry Aditia. "Kendala Pembelajaran Daring Guru Sekolah Dasar Di Banjarnegara." Elementary School: Jurnal Pendidikan dan Pembelajaran ke-SD-an 7, no. 2 (July 2020): 297302.

Sadikin, Ali, and Afreni Hamidah. "Pembelajaran Daring Di Tengah Wabah Covid-19." Biodik 6, no. 2 (2020): 109-119.

Saleh, Ahmad Muzawir. "Problematika Kebijakan Pendidikan Di Tengah Pandemi Dan Dampaknya Terhadap Proses Pembelajaran Di Indonesia." Jurnal Pendidikan 2, no. 2 (2020): 24-24.

Santosa, Ari Budi. "Potret Pendidikan Di Tahun Pandemi : Dampak COVID-19 Terhadap Disparitas 
Pendidikan Di Indonesia." CSIS Commentaries (2020): 1-5.

Satrianingrum, Arifah Prima, and Iis Prasetyo.

"Persepsi Guru Dampak Pandemi Covid-19

Terhadap Pelaksanaan Pembelajaran Daring Di

PAUD.” Jurnal Obsesi : Jurnal Pendidikan Anak

Usia Dini 5, no. 1 (2020): 633.

Smith, Kevin Gary. Writing and Research: A

Guide for Theological Students. Cumbria:

Langham Global Library, 2016.

Zaluchu, Sonny Eli. "Metode Penelitian Di Dalam

Manuskrip Jurnal Ilmiah Keagamaan.” Jurnal

Teologi Berita Hidup 3, no. 2 (March 25, 2021):

249-266. https://e-

journal.sttberitahidup.ac.id/index.php/jbh/article

/view/93. 